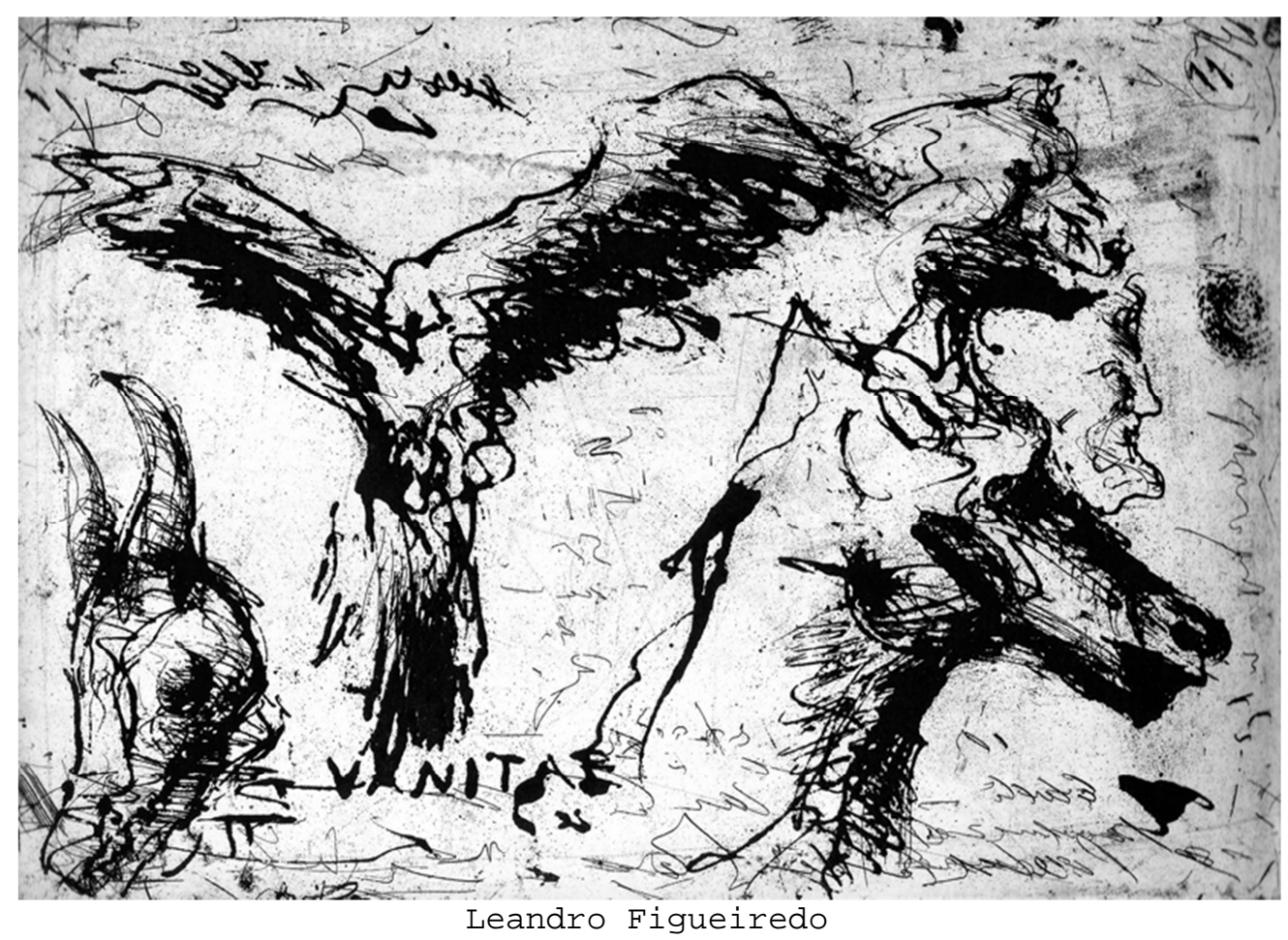

\title{
NÉVOA INSOLVENTE
}

\section{João Jarbas Damasceno}

Bioquímico e farmacêutico. Foi vencedor, por dois anos consecutivos, do Concurso de Poesias promovido pela Universidade Federal de São João del-Rei. Participou do Concurso Raimundo Corrêa, no Rio de Janeiro, tendo seu poema publicado no livro Poetas brasileiros de hoje.

Que podemos guardar

em memória falha

que de desvanecer-se

que é o estar

se talha.

Ou persistir-se fome imemorial.

Venenos de beijos, serenos de estrelas, tudo se vai com a fúria de nós.

Onde? O acabado menino, a quem um terreno de mato, de bastar assombrava e que vida não bastou. 


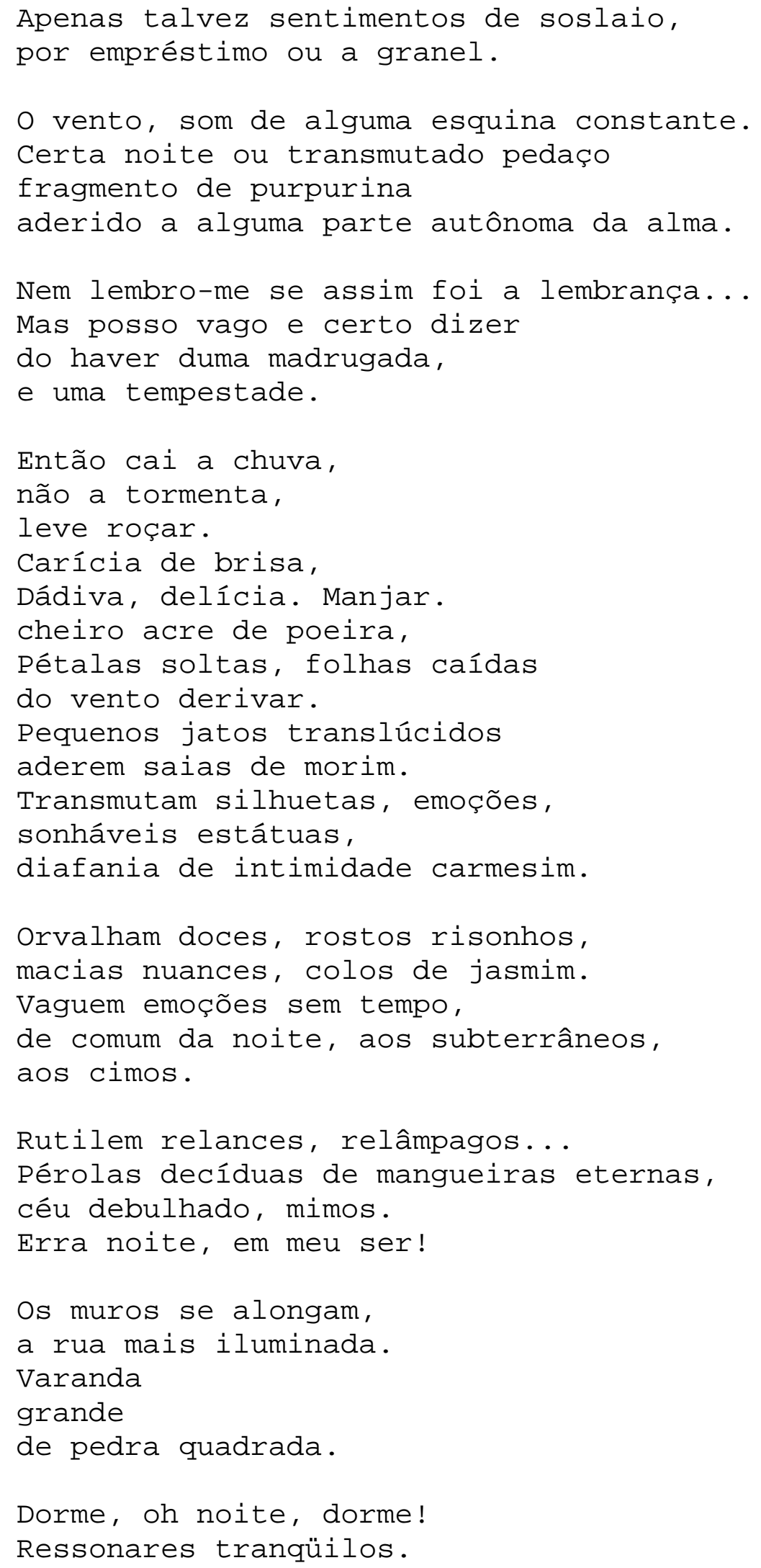


Casas fechadas, portas molhadas, Janelas do império.

Cortinas, corridas,

doces, (intangíveis) mistérios.

Noites caladas, ecos,

pés migrantes.

Espaço aberto, espírito,

peito liberto.

Corpo leve,

fronte cingida-louros furtadosaurora breve.

Alma orvalhada, vontades pungidas.

Rastros descalços,

saudades compridas. 